Hazel Patmore and Norah Lane attended the 5th Annual Meeting of the North American Bluebird Society (NABS), November 5, 6 and 7, at Southern Pines, North Carolina. On field trips, new types of nest boxes were seen, and small flocks of Eastern Bluebirds were a delight. In the Longleaf Pine woods they were fortunate to see the rare Red-cockaded Woodpecker and the uncommon and local Bachman's Sparrow. Other new sightings for them were the Red-bellied Woodpecker and Brown-headed Nuthatch. An award in the name of John and Norah Lane established by NABS was presented to four awardees by Norah Lane.

An enlarged coordinating committee was formed and new leaders secured for the Brandon Junior Birders. Members of the coordinating committee are Norah Lane (coordinator), Barbara Robinson, Hazel Patmore, Mamie McCowan, Ann Smith, David Barnes and
Cliff Findlay. Bob and Jean Horton are the Junior Birders' leaders.

New members of The Friends of the Bluebirds include the following: Alexander - Mr. and Mrs. John Thiessen; Baldur - Jim and Irene Cramer; Bethany - Gerald Fischer; Brandon David Barnes, Morley Brotherston, Raymond Gladden, Helen and Kris Larson, Kae Longrigg, Nancy McLennan, Garnet and Martha Northcut, Frank and Arleen Vegso, Eleanor Wilde; Carberry - Howard and Elsie Kneeshaw; Dauphin - Mr. W. J. Walley; Kemnay - Verda Topham; Killarney - Dr. David and Ruth Stewart; Lyleton John Murray; Minnedosa - Mr. and Mrs. G. Stemmer; Neepawa - Barry Strohman, Cal Whelpton; Rapid City Edie Evans; Rounthwaite - Graham Eagleton; Treesbank - John Clark; Virden - Patrick Cox. Junior groups added were Minnedosa Junior Gardeners and Rapid City Summer Recreation Group.

\title{
PRINCE ALBERT BLUEBIRD TRAIL REPORT - 1982
}

KIM HRUSKA, 841 - 22nd St. East, Prince Albert, Saskatchewan S6V 1N9 and KEVIN ASCHIM, 1175 - 22nd St. East, Prince Albert, Saskatchewan. S6V 1P2

This is a summary of results obtained from the Prince Aibert Bluebird Trail during the 1982 season. The houses were monitored from 26 June through 24 July.

Early in 1982 we decided to reorganize our trail so that more of it would pass through grassland and pasture. Because of this our trail now is divided into two parts, one extending out to Red Deer Hill and St. Louis and the other to Round Lake and Holbein. This change certainly increased our
Mountain Bluebird nesting results, with a total of 14 nests, as well as decreased numbers of House Sparrows.

Prince Albert and district was fortunate this spring to have avoided most of the snow which much of southern Saskatchewan received at the end of May. Although the cold weather was probably responsible for the loss of one set of bluebird eggs which were laid early, and a delay in the Tree Swallow nestings by approximately one week, the rest of the results appeared normal. 
The average Tree Swallow clutch size fell from a 1981 level of 5.7 to 5.3, perhaps due to the late start.

Of the House Wrens which nested in our boxes, all were found in boxes which were put up in the beginning of May and in an area of scrub poplar forest, both of which may account for the wren's presence there and nowhere else on the trail.

Other inhabitants included a whitefooted mouse as well as a dead garter snake. It is possible that the garter snake may have been in search of eggs or young birds.

In a total of 118 bird boxes there were 135 attempted nestings. The occupancy rate of useable boxes was $97.4 \%$.

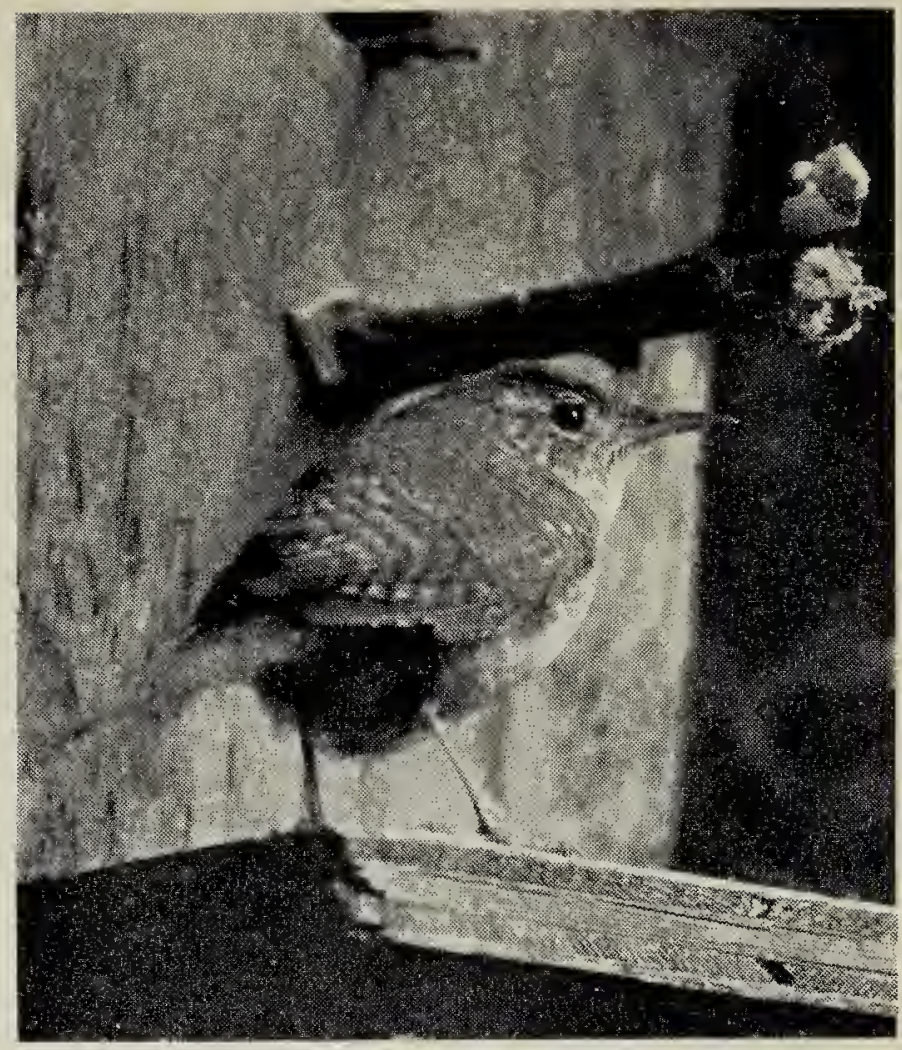

House Wren
Doug Gilroy

Table 1. PRINCE ALBERT BLUEBIRD TRAIL RESULTS IN 1982.

Species

Tree Swallow House Sparrow Mountain Bluebird House Wren Empty

*All eggs destroyed

$\begin{array}{rrrrrrr}\text { No. } & \begin{array}{r}\text { No. } \\ \text { Eggs }\end{array} & \begin{array}{r}\text { Young } \\ \text { Fledged }\end{array} & \begin{array}{r}\text { Addled } \\ \text { Eggs }\end{array} & \text { Mortality } & \begin{array}{r}\text { Clutch } \\ \text { Size }\end{array} & \begin{array}{c}\text { Ave. No. } \\ \text { Fledged }\end{array} \\ 94 & 497 & 465 & 32 & 6.4 \% & 5.32 & 4.98 \\ 9 & 36^{*} & - & - & - & - & - \\ 14 & 67 & 58 & 9 & 15.5 \% & 4.79 & 4.14 \\ 5 & 11 & 10 & 1 & - & 2.2 & 2.0 \\ 13 & & & & & & \end{array}$

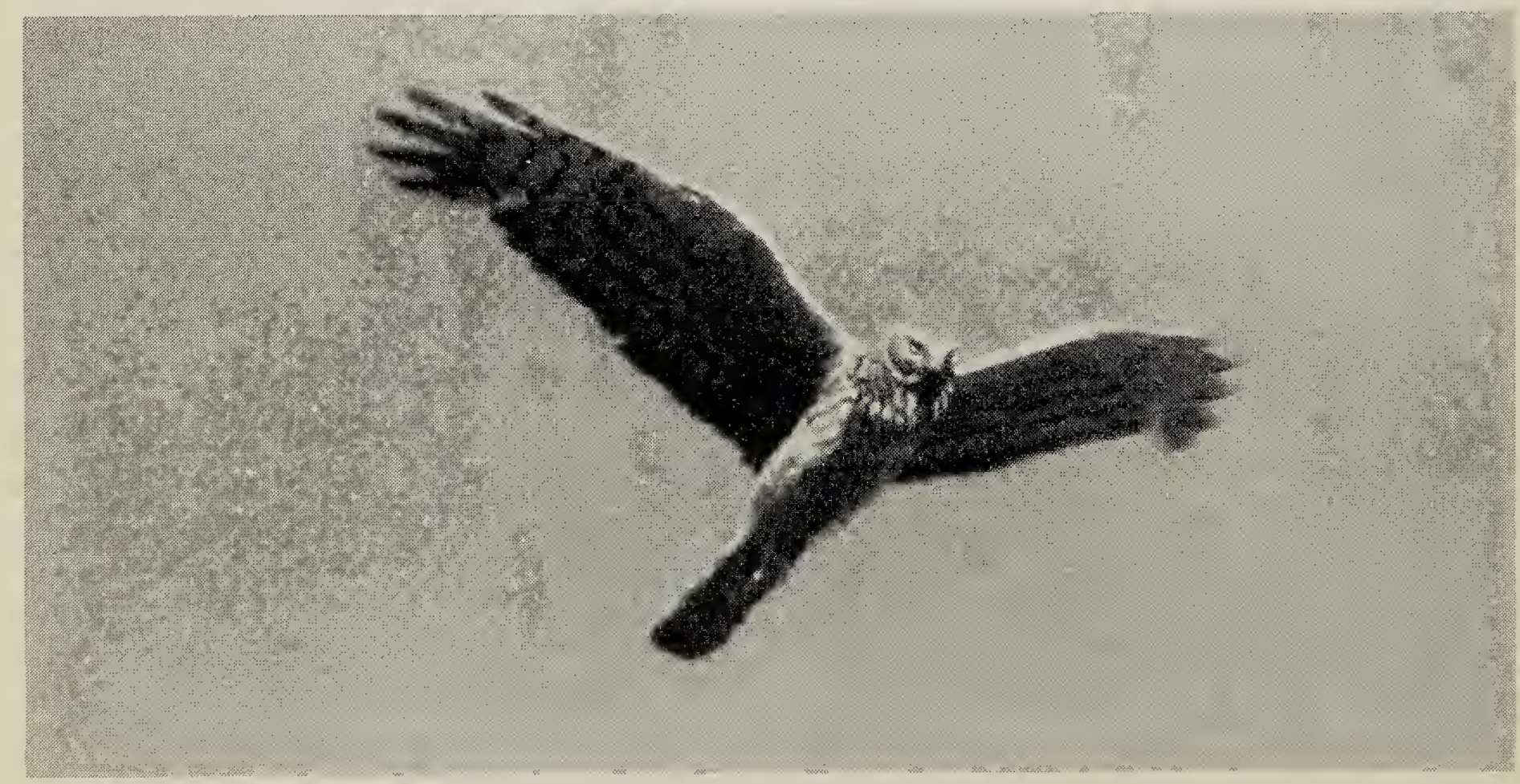

